\section{Backing the wrong horse}

Sir - As the author of the foreword to Stephen Budiansky's book The Nature of Horses, I was amazed by the inaccuracies in Marian Dawkins' review (Nature 386, 341-342; 1997).

The reviewer's first sentence is incorrect - nowhere on the book jacket or in any of the book's pages does the quoted blurb appear*. If the reviewer means some publicity the publisher sent with the review copy, then potential purchasers will never have seen it anyway. The reviewer then grumbles that the book doesn't live up to "its claim to cover everything one might want to know about horses". In fact, the subtitle is "Exploring Equine Evolution, Intelligence and Behavior", not "everything".

The reviewer also complains that the book "draws upon the work of other people". Most books do, but Budiansky is scrupulous in citing sources.

Franklin M. Loew

Medical Foods, Inc.,

201 Broadway, 5th Floor,

Cambridge, Massachusetts 02139, USA

*The offending phrase appeared in proofs of the book. Before DrDawkins' review appeared, Nature should have sent her a finished copy of the book. Editor, Nature

\section{Space can wait}

Sir - Yet another new (in effect) species has been discovered in the Annamite Mountains on the Laos/Vietnam border ${ }^{1}$. It is going to cost millions, perhaps billions, of dollars to find out whether there might have been a bacterium on Mars in the distant past. It probably didn't take more than a few thousand dollars to rediscover Sus

bucculentus, which is not a bacterium but a pig, a massive lifeform, as are a number of the other mammals still being discovered through the second half of this century.

Why do we spend so much to discover life on Mars and so little on discovering new life on our own Earth? There's another contrast too. It's not going to make the slightest difference to what we find on Mars whether we go now or in a hundred or even a thousand years' time. If the bacterium's traces are there now, they'll be there then. And the same goes for the search for new stars and galaxies, but more so: the Universe isn't going to look very different 10,000 years down the line from the way it does now. But one small part of it will be very different. If we don't find out now about present and new lifeforms on Earth, we will have lost the chance for ever: more and more species are 'dead as a dodo'. We can leave exploration of the stars and Mars to our great-grandchildren, our ten-greats grandchildren. We cannot leave exploration of the Annamites, or any of the other threatened areas of Earth ${ }^{3}$, even to our children.

I am not anti-astronomy: Hale-Bopp is going to be a memory of a lifetime. But space can wait; Earth can't. I have a suggestion. For every new observatory, every new Hubble (every new repair of Hubble!), exactly matching funds from the same source should be automatically provided for the discovery and identification of new lifeforms on Earth.

\section{Alexander H. Harcourt}

Department of Anthropology,

University of California,

Davis, California 95616, USA

e-mail:ahharcourt@ucdavis.edu

1. Groves, C. P., Schaller, G. B., Amato, G. \& Khounboline, K. Nature 386, 335 (1997).

2. Pine, R. H. Nature 368,593 (1994).

3. Morris, D. W. Nature 373, 25 (1995).

\section{USGS managers should consult customers}

Sir - The recent controversy about US Geological Survey Library cutbacks (Nature 386,631 ; 1997) is just one of a series of highly questionable management decisions from the Geologic Division as they are incapable of finding a foothold in shifting political sands.

Over a period of two years, the Geologic Division, through buyouts and a reductionin-force (RIF), lost more than one-third of its staff, including many key programmes and tremendous 'corporate' memory, experience and wisdom. These staff reductions, in effect, boosted their budget by more than $\$ 50$ million from a nearly constant congressional appropriation of $\$ 250$ million. How ironic that out of that surplus, a half-million dollars cannot be found to continue support of the library while millions are being spent to fight highly questionable RIF practices, including making women scientists redundant at a rate 70 per cent greater than their male counterparts, as well as all scientists with pending equal opportunity employment (EEO) complaints, and retaining all former managers (except the female who had a pending EEO complaint). This is a battle that will surely continue in the courts for many years to come even though settlements could be negotiated at a fraction of the continuing legal costs.

In large part, these controversies are generated because of the parochial attitude of the current Geologic Division management. While lip-service is given to serving customers, very little input is sought from those customers. The Geologic Division should realize that there are many companies and individuals, including those made redundant, willing to provide input and help to re-establish its stature as a venerable and unbiased institution. The continued arrogant exclusion of intellectual diversity by the Geologic Division greatly hampers the organization's ability to survive in a fast-changing political environment.

\section{G. Michael Reimer}

122 S. Devinney Street,

Golden, Colorado 80401, USA

e-mail:mreimer@mines.edu

\section{Public perception}

Sir - A strongly worded resolution of the European Parliament recently established that procedures for marketing genetically modified organism (GMO) products should be revised, opposing the European Commission's rule that a transgenic maize could be marketed. This was underpinned by concern about safety for consumers and the environment, and that decision-making procedures did not reflect the opinion of the European member states, where 13 of 15 had opposed the procedure.

But how had the member states reached their decisions? In Britain, little systematic information exists about public attitudes to genetic engineering of foodstuffs. A recent report (Uncertain Worlds) from the University of Lancaster highlights ambivalence towards the use of GMOs in foodstuffs. Our recently completed study explores the prevalence of views among 386 sixth-formers - the coming generation of voters and purchasers. More than half $(61 \%)$ were 'a bit worried'and a further $11 \%$ 'very worried' about genetic engineering. Some $59 \%$ agreed that it lengthened shelflife; $58 \%$ thought it extended the growing season. Fewer saw advantages of taste $(10 \%)$, economy (19\%) or 'healthiness' (9\%). Only $5 \%$ thought genetically engineered foodstuffs unsafe to eat, and $61 \%$ said they would eat such products. For $17 \%$, genetically modified plants were an environmental risk. In several issues many students gave 'neutral' responses, so people may remain persuadable. In contrast, $86 \%$ thought genetically engineered foods should be labelled.

Such appreciation of lay people's views is essential if there is to be a claim to 'democracy'; views can be represented only if they are known.

\section{Ruaraidh Hill}

Martin Stanisstreet

Edward Boyes

Environmental Education Research Unit,

University of Liverpool,

Liverpool L69 3BX, UK

e-mail:martstan@liv.ac.uk

\section{Helen O'Sullivan}

Liverpool Hope University College,

Hope Park, Liverpool L16 9JD, UK 